\title{
Yugoslavism Between the World Wars: Indecisive Nation- Building
}

\author{
Pieter Troch
}

\begin{abstract}
This article examines Yugoslav national programs of ruling political elites and its concrete implementation in education policy in interwar Yugoslavia. It is argued that at the beginning of the period Yugoslavism was not inherently incompatible with or subordinate to Serbian, Croatian or to a lesser degree Slovenian national ideas. However, the concrete ways in which Yugoslavism was formulated and adopted by ruling elites discredited the Yugoslav national idea and resulted in increasing delineation and polarization in the continuum of national ideas available in Yugoslavia. Throughout the three consecutive periods of political rule under scrutiny, ruling elites failed to reach a wider consensus regarding the Yugoslav national idea or to create a framework within which a constructive elaboration of Yugoslav national identity could take place. By the end of the interwar period, the Yugoslav national idea had become linked exclusively to conservatism, centralism, authoritarianism and, for non-Serbian elites at least, Serbian hegemony. Other national ideas gained significance as ideas providing viable alternatives for the regime's Yugoslavism.
\end{abstract}

\section{Keywords}

Yugoslavism; interwar Yugoslavia; ruling political elites; education policy; Royal Dictatorship of King Aleksandar

\section{Introduction}

Within the context of the disintegration of Yugoslavia, historians of Yugoslav national identities and nationalisms have been primarily concerned with what Rogers Brubaker has termed state-seeking nationalisms (9), focusing on the wide spectrum of national ideologies which demanded the reorganization of Yugoslavia's political structure and later the dissolution of Yugoslavia for the case of their respective nations. Some historians have traced the roots of these nationalisms back to ethnic/national identities which had emerged before the foundation of the Kingdom of Serbs, Croats and Slovenes in 1918. Accordingly, it was the competition between clearly defined and delineated Serbian, Croatian and to a lesser degree Slovenian national identities that determined the history of the Yugoslav state. Underlying this is an approach that conceives of national identities as clearly bounded and singular concepts. They might evolve slightly during a formation process, but after that process is completed no more significant alterations occur. In his standard book on Yugoslavia's national question Ivo Banac for example states:

\footnotetext{
Yugoslavia's national question was the expression of the conflicting national ideologies that have evolved in each of its numerous national and confessional communities, reflecting the community's historical experiences. These ideologies assumed their all but definite contours well before the unification and could not be significantly altered by any combination of cajolery or coercion. (406)
}

Thus, in Banac's view, Serbian, Croatian and Slovenian national identities became fixed prior to the foundation of the Yugoslav kingdom in 1918. Consequently, the interwar period was of 
no real significance for the national question in Yugoslavia. If anything, according to Banac, during that period "the national movements against centralism - particularly prominent among the Croats - merely completed the process whereby each group's national individuality was firmly set" (407). Within such an approach, there can be no place for a genuine or viable Yugoslav national idea. ${ }^{1}$ In a recent study Jovo Bakić for example has argued that Yugoslavism should be seen as a form of pan-nationalism, subject to competition between the different ethnic nationalisms that had developed within the South Slav lands (esp. 49-50).

Recently, Dejan Djokić has presented an alternative approach for the study of interwar Yugoslav history, arguing that "interwar Yugoslavia cannot be understood as a simple SerbCroat dichotomy (Elusive Compromise 1)." Taking Djokić's arguments as a starting point, I will focus on the Yugoslav national idea as it was defined by ruling political elites during the interwar period and argue that it would be too simplistic to reduce it to a merely tactical choice to promote a well established and fixed Serbian or Croatian national ideology. ${ }^{2}$ Instead, this article will examine Yugoslav national ideologies of the ruling political elites as an important factor within the dynamics of national identities in interwar Yugoslavia: it will contribute to the examination of the period not as an epilogue in the crystallization process of national identities, but as a period during which important variations came about in conceptions about and relations between national identities.

Following the dynamic approach toward national identities as outlined by Zimmer and Kaufmann, I consider national identity to be "a public project rather than a fixed state of mind" (Zimmer 174). According to Kaufmann's stimulating optical model of identity, national identities are constantly defined and re-defined as the product of the juxtaposition of a territorial and human population referent, interpretive lenses and symbolic resources. "Each lens" - Kaufmann distinguishes between ideologies, instrumental considerations, social and geographic perspectives, and psychological predispositions - "refracts light from the national referent upon certain symbolic resources to create a distinct national identity for each individual" (473). When individual national identities overlap, elites can codify collective national discourses. If these discourses become accepted by wider layers of the population, they themselves act as ideological lenses (Kaufmann 466-70). The resulting national identities should be seen as dynamic concepts, constantly open to variations, diachronically as well as synchronically.

Within the framework of such a dynamic model, it becomes clear that the formation of a Yugoslav state, with all its implications, must have caused variations in discourse and in practice within national ideas available in Yugoslavia. As Brubaker makes clear, "forms of nationalism that have resulted from the nationalization of political space are different from and less familiar than - those that helped engender it" (4). I will focus on ruling political elites and examine in which way they redefined their national ideologies within the context of the new Yugoslav state. I will show that they conceived of a Yugoslav nationalization of the political and cultural space, i.e. they propagated a specific Yugoslav national identity which was to find expression within the Yugoslav state. By focusing on ruling political elites, I do not intend to claim that they were all-powerful in constructing national identities. However, it is undeniable that they did act as an important factor in the dynamics of national identities in interwar Yugoslavia. Indeed, the national ideologies formulated by political elites act as fundaments for concrete nation-building policies. Additionally, individuals, as well as competing elites formulate their national discourse in a political and cultural space which is nationalized along the lines of the national discourse of the ruling elites. Thus, we will see that the concrete ways in which Yugoslavism was formulated and adopted by the ruling elites was one of the factors which discredited the Yugoslav national idea itself and resulted in 
increasing delineation and polarization in the continuum of national ideas available in Yugoslavia during the period.

I will distinguish between three consecutive periods of political rule in interwar Yugoslavia. I will focus first on the period from the unification of the Kingdom of Serbs, Croats and Slovenes on 1 December 1918 to the proclamation of the Royal Dictatorship on 6 January 1929. I will examine the national discourses of the two leading political parties, the Radical Party and the Democratic Party and argue that the Radicals' Serb centered, compromised Yugoslavism was prevailing. During the Royal Dictatorship, which lasted from 6 January 1929 until the elections of 5 May 1935, the King and his Council of Ministers proclaimed the ideology of integral Yugoslavism as the cornerstone of Yugoslav politics. Finally, the government of Prime Minister Milan Stojadinović (May 1935 - February 1939) formulated a so-called real Yugoslavism. ${ }^{3}$ It is clear that this article will mainly deal with Serbian elites, partly because Serbian politicians were overrepresented in Yugoslav governments of the interwar period. More importantly however, as this article will show, there was a considerable overlap between Serbian and Yugoslav identities and, more than other elites, Serbian political elites remained favorable toward Yugoslavism throughout most of the interwar period. The period after the 1938 elections will not be treated. In August 1939 an agreement was reached between Prime Minister Dragiša Cvetković and Croat opposition leader Vladko Maček whereby an autonomous Croatian unit was created. During this period of political and ideological transformation, Yugoslavism as a national ideology was clearly losing ground. Since I am interested primarily in the Yugoslav character of the elites' national ideas, I will only treat this period in passing.

For each of these periods I will discuss the national ideology of the ruling political elites through an examination of the nationalist elements within their discourse. Apart from governmental declarations, programs et cetera, this article will also discuss national ideas as they were transmitted through education policy. Because education was considered one of the most effective means to nationalize the Yugoslav population, the national ideology of the ruling elites can be easily traced in curriculums and education laws. This article does not intend to examine how these Yugoslav national ideologies were received by the population at large. Rather, it will focus on the top level of the Yugoslav society and argue that although all Yugoslav governments during the interwar period adopted some form of Yugoslav national ideology as one of the central elements of their politics, they failed to formulate and adopt a consistent Yugoslav national idea as a basis for constructive negotiations with other representative elites.

\section{The parliamentary period (1918-1929)}

During the so-called parliamentary period between the unification of the Kingdom of Serbs, Croats and Slovenes on 1 December 1918 and the proclamation of the Royal Dictatorship on 6 January 1929, the two dominating political parties were the People's Radical Party (NRS, Narodna radikalna stranka) and the Yugoslav Democratic Party (JDS, Jugoslovenska demokratska stranka). The Radicals were part of 21 of the 24 governments in office. In all but one of those governments they provided the Prime Minister. In sum they spent just less than 10 months in opposition. Before the Democratic Party split up in March 1924, it took part in 9 of the 12 governments in office during this period. ${ }^{4}$ Although the position of the Democrats and the Independent Democrats weakened after the 1924 split, each of the parties still participated in four more governments. Additionally, these parties enjoyed the support, although not unqualified, of King Aleksandar, who had far-reaching political authority and should thus be seen as an important factor in Yugoslav politics. ${ }^{5}$ 
Before the unification of Yugoslavia, one of the Radical Party's main goals had been the liberation and unification of all Serbs (Bakić 298-99). ${ }^{6}$ Under the changing circumstances of the Balkan Wars, the First World War and the formation of the Yugoslav Kingdom in 1918, they gradually redefined their national ideology toward a compromised Yugoslavism, propagating the existence of the Yugoslav nation while at the same time recognizing three different parts within that nation. The Radicals considered the Yugoslav nation a so-called three-named nation (troimeni narod) consisting of a Serbian, Croatian and Slovenian tribe. ${ }^{7}$ Different historical developments had led to the formation of these tribes within the Yugoslav nation, each with its own characteristics. However, these differences did not harm the national unity of the Yugoslav nation and each tribe should be able to preserve its characteristics within a larger Yugoslav national unity. Although in official statements the party was quick to recognize "that this state [was] composed out of Serbs, Croats and Slovenes and that its process and future depend[ed] on the joint work of all three national parts, all three branches of our single nation" (qtd. in Bakić 344), ${ }^{8}$ its national ideology remained Serb centered, because it was clear for the Radicals that the Serb tribe deserved to take the leading role within the Yugoslav nation since Serbs had put most efforts in the unification and liberation of the Yugoslav tribes. In the words of Nikola Pašić, the party's leader until his death in 1926, in a comment on the much disputed constitution of 1921:

When we built this constitution some of us demanded some sort of autonomy for the Croats. Serbia has suffered so much for this unification and liberation that it could not agree with that. We didn't want them to be servants and we masters, but we had to make it clear that we - Serbs - were the ones who fought for freedom and made unification possible. (Qtd. in Stanković 265)

The explicit Greater-Serbian character of the following citation from Samouprava is not really representative of the more diplomatic discourse of Radical politicians but makes clear how vague boundaries between Yugoslavism and Greater-Serbianism could be:

\footnotetext{
The Serbs came into being - that is, the Serb name, the idea of Serbdom, and the Serb national consciousness - after a certain primary tribe, called Serb, separated itself from the other tribes by virtue of its number, power, and the intelligence of its elders and leaders, and succeeded in excelling [among the other tribes], and distinguishing and uplifting itself. And so the Serb name spread in all directions as the original Serb tribe increasingly succeeded in drawing the other neighboring, less powerful, and less important tribes into its [political] community. ${ }^{9}$ (Qtd. and translated in Banac 162)
}

Clearly, the Radicals wanted to preserve Serbian traditions as dominant elements within the Yugoslav national identity. Consequently, the Yugoslav national identity which they defined relied overwhelmingly on symbolic resources linked to the Serbian tribe. In discussions concerning the literary unity of the Yugoslavs the Radicals always favored the Cyrillic over the Latin alphabet, claiming that the former was more naturally linked to Serbo-Croatian phonetics, that it was a Slavic alphabet whereas the Latin script was foreign (Dimić 1: 19198). Another important set of symbolic resources for the Radicals were linked to the Serbian state tradition that was to be preserved within Yugoslavia. As Pašić's previous quotation shows, the Radicals continuously stressed that it was the Serbian state, under the leadership of the Serbian dynasty, which fought and suffered most for the Yugoslav state, pointing at the fresh memory of the Balkan wars of 1912/1913 and the First World War, the so-called wars of national liberation and unification. In a similar way we should interpret their insistence on the official name of the new state: Kingdom of Serbs, Croats and Slovenes, and its language: Serbian-Croatian-Slovenian. ${ }^{10}$ These names make clear that the Radicals saw the Yugoslav nation as a nation consisting of three tribes, under the leadership of the Serbian tribe.

The Democrats were, definitely in the first years after the war, much more explicit in their Yugoslavism than the Radicals and left a firm mark on the national discourse of the 
period. The party was the fiercest advocate of a Yugoslav nation-state. Important in this respect was that JDS was the only truly Yugoslav party, in the sense that it was the only party with representatives from all over Yugoslavia, being formed in 1919 out of several pre-war parties, most importantly the Croat-Serb Coalition and the Slovenian Liberals from AustriaHungary, and the Independent Radical Party from pre-war Serbia (Gligorijević, Parlament 37-38). In the 1920 party program the integral Yugoslavism of the Democrats was clearly formulated:

The Democratic Party considers the Serb, Croat and Slovene people as one national unity by blood, language and sentiments, because of the continuity of the lands where it has inseparably lived and by the joint vital interests of its national survival. In accordance with such an interpretation of national unity and in order to strengthen the national state community for the idea of one Yugoslav nation and state, the Democratic Party excludes all historical, tribal, religious and regional differences as reasons or fundaments for the political and administrative organization and regional separation [of the country]. The Democratic Party will nurse and develop the consciousness of the unity of our people and state throughout the widest layers [of the population] and will strive for that unity to come to expression in all political, social, cultural and economic questions and to wipe out all deeds of separatism, demagogy and poverty of the general social morale. (Qtd. in Čulinović 172)

Contrary to the compromised Yugoslavism of the Radicals, the Democrats saw the Yugoslav nation as one and indivisible. The Democratic Party did not leave tribal differences unmentioned, but held that they should and would disappear within a very short period of time. Contrary to the Radicals, the Democrats insisted that the state should play an active role in spreading Yugoslav national consciousness and in wiping out any "superficial"

differences (Banac 185-86; Dimić 1: 198-203).

However, partly because the political influence of the Democrats decreased throughout the twenties, but also because of the general political instability of the period, the integral Yugoslavism of the Democrats was never really put into practice before 1929. All official declarations and speeches referred to the unity of the Yugoslav tribes and how differences between them were only superficial and would disappear within a short period of time, but very little was actually undertaken to promote this national rapprochement. The recurring debates on education policy are exemplary. Every new minister, Radical or Democrat, started his mandate claiming that he would do everything possible to unite the education system, to raise children in the Yugoslav spirit as mentioned in the Constitution. ${ }^{11}$ A whole range of commissions were appointed to unify the education system, but owing to the continuous alternation of ministers and personnel in the Ministry of Education few of their proposals were ratified before 1929 and Yugoslavia's education system remained fractured along the pre First World War-borders (Mayer 57-80; Tešić 89-100). The Ministry of Education did adopt some unified curriculums, which were clearly intended to spread a Yugoslav national identity. According to the curriculums for lower elementary schools especially the history courses were intended to arouse national, Yugoslav feelings, by paying attention to the common Yugoslav character of the independent medieval kingdoms and the parallel Serbian, Croatian and Slovenian attempts toward liberation from foreign rulers. ${ }^{12}$ Generally, the three tribes were equally represented, although the attention that was paid to the Serbian state and its role as 'Yugoslav Piedmont' could be perceived as Serbian dominance (Kingdom of SCS "Nastavni program" 12-14). A clearer example of the dominance of Serbian symbolic resources was the decision made by the Ministry of Edcuation on 22 September 1928 to impose St Sava's Day as an official school holiday and St Vitus' Day as the last day of the school year. However, it should be mentioned that the birthday of Josip Strossmayer, a bishop and politician in Croatia in the second half of the $19^{\text {th }}$ century famous for his Yugoslav orientation, was also established as an official school holiday (Aranicki and Karadžić 160-62). Apparently this decree was not properly implemented and the Ministry immediately 
thereafter, on 28 December 1928, issued a special decree warning that the celebration of St Sava's Day should be conducted in the spirit of religious tolerance and Yugoslav national unity, especially in religiously mixed schools (163-64).

Thus, the ruling elites' national ideology of the period inclined toward the Radicals' Serb centered, compromised Yugoslavism. It was compromised, because tribal differences were tolerated. It was Serb centered, because the Serb tribe obviously took the leading role. However, it was also Yugoslav, because the existence of a Yugoslav nation was accepted and took a very prominent place in the national discourse of the ruling elites, especially in the integral Yugoslavism of the Democrats, but also in the compromised Yugoslavism of the Radicals. Contrary to scholars who downplay the Yugoslav element in the discourse of the period and claim that the national ideologies of the Radicals and the Democrats were tactical choices to protect Serbian national interests within Yugoslavia, ${ }^{13}$ in my opinion the Yugoslavism of the ruling elites cannot be seen as inherently subordinate to or well delineated from clearly defined and established "narrow", in this case Serbian national identities. Although regional/tribal/national interests played a role as interpretative lenses in the formation process of national identities of the ruling elites, the end product could still be some form of Yugoslavism, albeit Serb centered. ${ }^{14}$ Indeed, within the growing body of literature on sub-national or regional identities - within the rhetoric of the Yugoslav Kingdom tribal identities - it is accepted that:

\footnotetext{
the region serve[s] as a category of perception, of "vision and division" of the world, just as capable of making sense of changes in collective life as [is] the nation - in fact, eminently capable for making sense of the nation itself. This perspective enables us to account for the specific forms that national identity has taken, which vary from place to place, and to open it up as an arena of conflict and negotiation, not coercion and manipulation. (Applegate 1177)
}

However, because the Yugoslavism of the ruling elites was defined as an exclusively centralist and Serb centered concept, there was little place for the necessary cooperation and negotiation with representative elites other than the dominant Serbian parties with regard to Yugoslav national identity. Whereas at the beginning of the twenties a great majority of the political and cultural elites did favor the Yugoslav national idea and were willing to participate in negotiations over the concrete definition of Yugoslav national identity, by the end of the parliamentary period the viability of the Yugoslav national idea had seriously decreased in the eyes of competing non-Serbian elites. ${ }^{15}$

\section{The Royal Dictatorship (1929-1935)}

On 6 January 1929 King Aleksandar dissolved parliament and installed a Royal Dictatorship, the ultimate goal of which was to preserve Yugoslav national unity. As the king put it in his declaration:

Instead of developing and strengthening the spirit of national and state unity, parliamentarism - such as it is - is beginning to lead to spiritual disintegration and to national disunity. It is My sacred duty to employ all means to preserve State and National unity. And I have resolved to fulfill this duty without hesitation to the end. To preserve national unity, and the integrity of the state, that is the highest goal of My Reign, and that must be the greatest law for Me and for everyone. (Qtd. and translated in Nielsen 124)

King Aleksandar appointed a Council of Ministers and within a short period of time a large amount of new laws were adopted in order to sanction integral Yugoslavism as the official state ideology. ${ }^{16}$ The Law on the Protection of Public Security and Order in the State forbade all political parties or organizations that were based on religious or tribal characteristics. Only 
organizations which adopted the official national ideology of integral Yugoslavism were permitted (Kingdom of SCS, "Zakon o zaštiti" art. 3). The new Law on the Press forbade all publications that spread hatred against the state as a unity, or any form of tribal or religious discord (Kingdom of SCS, "Zakon o izmenama" art. 3). A Central Press Bureau was installed to check domestic and foreign publications (Kingdom of SCS, "Zakon o presbirou"). The most important law in this respect was the Law on the Name and Division of the Kingdom in Administrative Regions. From then on the state was called Kingdom of Yugoslavia and was divided in 9 administrative regions, called banovine (plural, the singular form is banovina), while the city of Belgrade and its surroundings formed a separate administrative unit (Kingdom of SCS, "Zakon o nazivu" arts. 1-4). ${ }^{17}$ According to the regime, the boundaries of the new banovine were drawn in correspondence to natural, economic and communicative factors. They replaced "historical boundaries, those obstacles to our national formation and development" by "strong and viable administrative and economic units." 18 The new name of the state "not only reflect[ed] the complete unity of our state and nation but also symbolically express[ed] the idea of full similarity, equality and brotherhood of us, Slavs of the South, Serbs, Croats and Slovenes." ${ }^{19}$ Equally important for national unification was the foundation of the Sokol of the Kingdom of Yugoslavia. ${ }^{20}$ The Sokol replaced all previously existing, tribal youth gymnastics movements "to raise physically healthy, morally strong and nationally conscious citizens of the Kingdom of Yugoslavia" (Kingdom of Yugoslavia, "Statut" art. 1). ${ }^{21}$

This short overview of the legislation policy during the first year of the dictatorship clarifies to what extent integral Yugoslavism was endorsed as the official national ideology in legislation. However, how did the regime define this Yugoslav national identity? King Aleksandar's inauguration speech to the new National Parliament on 18 January 1932 provides us with one of the clearest formulations of the official national idea. ${ }^{22}$ Accordingly, the Yugoslavs had settled in the Balkans as a homogeneous nation. External factors had led to the separation of the Yugoslav nation into three tribes, but differences between them were only superficial and "in the end, the ethnical truth of the Yugoslav idea came across all the obstacles that were artificially formed throughout the centuries" (Karađorđević 1). However, the formation of a Yugoslav nation-state in 1918 had not immediately brought national unification, since political passions had led to chaos and division in the twenties. Only after 6 January 1929 the ethnical truth of integral Yugoslavism was fully realized (Karađorđević passim). Thus, the King did not completely deny tribal traditions, but claimed that the complete assimilation of all three tribes into one nation had been realized on 6 January 1929.

The regime tried to spread Yugoslav national consciousness among the population in several ways. In the political sphere, a new Constitution was adopted on 3 September 1931. The King remained the dominant political factor, but a semi-parliamentary system was installed and the people were invited to cooperate with the King in his Yugoslav project through semi-democratic elections. The Constitution and election laws made sure that only parties that supported integral Yugoslavism and enjoyed the support of the new political elite could take part in the elections, and that the party that won the elections would surely dominate the parliament. Indeed, the only candidates participating in the elections of 8 November 1931 were on the governmental list headed by Živković. The turnout of $66 \%$ was interpreted as a confirmation of the public's satisfaction with the new regime. After the success of the elections attempts were made to form a mass political participation platform in the Yugoslav spirit. On 15 December 1931 the Deputies' Club of the National Parliament accepted a mutual political program and on 18 December 1931 the Yugoslav Radical Peasant Democracy (JRSD, Jugoslovenska radikalno-seljačka demokratija) was formed. The party was renamed into Yugoslav National Party (JNS, Jugoslovenska nacionalna stranka) on 21 July 1933 (Dobrivojević 122-34; Nielsen 385-414; Stojkov, Opozicija 133-43). Party members organized gatherings all over the country in order to create a Yugoslav national 
movement that would organize "the people in the spirit expressed in all the important acts since 6 January 1929." 23 The official party program adopted at the party congress of 20-21 July 1933 started with a clear formulation of its integral Yugoslav ideology:

Serbs, Croats and Slovenes form one unified Yugoslav nation because they have lived on one cohesive territory, because of their equal geographic and ethnographic structure, by their origin, by their language, by their century-long aspirations, by the sameness of their historical destiny and experiences, by their never extinguishing consciousness and community. Therefore Yugoslav national unity is an irrefutable and natural fact.

The national thought in every national part during our entire national past has in reality always been Yugoslav, because it was identical, although it has been expressed and named in different ways. By means of the liberation and the voluntarily realized unification of Serbs, Croats and Slovenes in one indivisible national state - based on the fundaments of the self-determination of nations - the Yugoslav national idea forever became the one and only mark of national unity and the fundament of all national life, the one and only exclusive national idea, the guiding principle of the entire Yugoslav nation.

The equal and harmonious efforts of our entire unified nation have to lead to the preservation, development and assimilation of all cultural, economic and social inheritances, which were obtained in separate pasts, into a general and common national good. In addition, new heritages have to be acquired in the future and the national unity in the harmony of all our authentic properties has to be constantly strengthened and enhanced. ("Načele" 2-3)

Apart from the mobilization of the masses in a mass political movement, the regime also tried to spread integral Yugoslav national consciousness through education reforms. What Minister of Education Božidar Maksimović said for primary education, that its goal was "not only to spread literacy, but also, even more, to educate nationally," 24 counted for the entire education system. As the daily Jugoslovenski dnevnik wrote: "all [...] educational institutions first of all have to serve the idea of national unity and the development of the Yugoslav ideology" ("Za uspešno sprovođenje" 1). ${ }^{25}$ Thus, in the course of 1929 and 1930 the Ministry of Education adopted a series of laws, which were intended to unify the education system in the Yugoslav national spirit. Also, new curriculums were issued in the place of the several curriculums that were used in the different historical regions before 1929. Arguably the most important of these curriculums was the 1933 curriculum for elementary schools. As in other curriculums that were adopted during the dictatorship the so-called national courses, i.e. literature/grammar, history and geography received much attention, since these were the courses where pupils were taught what it meant to be a Yugoslav and could develop their Yugoslav national consciousness (Kingdom of Yugoslavia, "Metodska uputstva" 3). ${ }^{26}$ One of the main goals of the literature/grammar lessons was "to develop the student's consciousness of national unity and national pride" (Kingdom of Yugoslavia, "Nastavni plan i program za osnovne škole" 1). Serbian and Croatian were considered as one Serbo-Croatian language. On 15 June 1929 the Ministry of Education issued orthographic instructions for all schools in Yugoslavia. The new orthography had been written by a commission under the leadership of the leading Serbian linguist of the period, Aleksandar Belić, and had to be used in education all over Yugoslavia. In addition, all textbooks had to be written in accordance to the new orthographic rules (Kingdom of SCS, "Pravopisno uputstvo" 2). Students had to learn both the Latin and the Cyrillic alphabet. ${ }^{27}$ Reading books should include extracts from authors from all the historical regions in Yugoslavia. In Slovenia the Serbo-Croatian language was taught one hour per week and one fourth of the texts in reading books should be in SerboCroatian (Kingdom of Yugoslavia, "Nastavni plan i program za osnovne škole" 1-3). In geography courses students should "get to know their fatherland and develop patriotic love toward it" (Kingdom of Yugoslavia, "Metodska uputstva" 29). Banovine were intended to become the primary regional spaces of identification. Pupils first learned about their own banovina and then about Yugoslavia; no longer were they part of a Slovenian, Serbian or Croatian region (Kingdom of Yugoslavia, "Nastavni plan i program za osnovne škole" 4-5). 
In history courses pupils should learn about the history of the Yugoslav nation. In practice, Yugoslav history was presented as the history of a nation that, after its arrival in the Balkans, was separated into three tribes by external enemies. All of these tribes fought against the enemy in order to re-unite and liberate their co-nationals in one Yugoslav nation-state. This ideal was realized after the First World War and on 6 January 1929. Events that are now generally considered to be part of the national history of Serbs, Croats, Slovenes, Montenegrins, Bosniaks or Macedonians were interpreted as parts of a common Yugoslav history. For example, history courses downplayed religious differences within Yugoslavia and stressed the common, Slavic character of the conversion to Christianity, not only for Orthodox regions, where this was generally accepted, but also for Catholics by pointing at Grgur Ninski and the reformation movement, both favoring the use of the Slavic vernacular for liturgy and religious writings. ${ }^{28}$ The battle of Kosovo was interpreted as a battle of all Yugoslavs against the Turks. All of the medieval empires were interpreted as attempts to unify all Yugoslavs, King Tvrtko I being the first to realize the dream of Yugoslav unification. ${ }^{29}$ The Yugoslav renaissance of the $19^{\text {th }}$ century was seen as a joint project of all three tribes: Serbia had Prince Mihailo Obrenović, Croatia had Josip Strossmayer, and Slovenia Janez Bleiweis. ${ }^{30}$ The creation of the Yugoslav state and the new political structure after 6 January 1929 were seen as the final steps toward the realization of the age-old Yugoslav dream (Kingdom of Yugoslavia, "Nastavni plan i program za osnovne škole" 5-7). ${ }^{31}$

If we take these declarations, political programs and curriculums as the most concrete formulations of the ruling elite's Yugoslav national ideology, we clearly see that it was conceived of as a synthesis of the different tribal traditions. From each of the tribes national ideologists selected those symbolic resources that could be interpreted in a Yugoslav way and detached them from their tribal interpretation. However, there was still a slight predominance of Serbian symbolic resources in this integral Yugoslav identity. According to the curriculum of 1933, the history courses in the third grade of elementary school - the first year of history education - should provide an introduction in Yugoslav national history through the biographies of 10 historical figures. Eight of them were part of the Serbian history, only two belonged to the Croatian and none to the Slovenian set of symbolic resources. ${ }^{32}$ But even if there was a slight predominance of Serbian symbolic resources, these resources were reinterpreted as Yugoslav national symbols. For the fourth grade, where a more detailed overview of Yugoslav history was envisaged, there was no predominance of Serbian historical elements (Kingdom of Yugoslavia, "Nastavni plan i program za osnovne škole" 5-7).

Whatever were the specific interests of the elites who constructed this integral Yugoslav national identity, one cannot call it a Serbian nationalism in disguise as Bakić does (401-08). When looking at the concrete formulations of this Yugoslavism, it is clear that it was designed to be a synthesis of Croatian, Slovenian and Serbian symbolic resources into a Yugoslav whole. However, the particular way in which the regime applied this national ideology very much discredited the idea of Yugoslavism itself. Precisely because the regime proclaimed Yugoslavism as the cornerstone of its authoritarian politics, opposition against the regime was also expressed as opposition against Yugoslavism. The Yugoslav idea, which had previously been a progressive idea, popular among intellectual circles in all parts of Yugoslavia and certainly not incompatible with Slovenianism, Croatianism or Serbianism, was more and more interpreted as a conservative, authoritarian, anti-national idea. That way, the process whereby Yugoslavism lost ground and other national ideas available in Yugoslavia gained significance as ideas providing viable alternatives for the regime's Yugoslavism - a process that had already been underway in the parliamentary period - only gathered momentum during the Royal Dictatorship.

On October 9, 1934 King Aleksandar was assassinated by Croatian and Macedonian terrorists during an official visit to France. The whole country was in shock. The government 
attempted to present Aleksandar as martyr for the Yugoslav national case, and the king's alleged last words "Save my Yugoslavia" were spread all over the country as the guiding principle for generations to come (Djokić, "(Dis)Integrating Yugoslavia" 136-37; Nielsen 454-62). It soon became clear, however, that Aleksandar's death had left the ruling political elite without any legitimacy. At the May 1935 elections the governmental list headed by Prime Minister Bogoljub Jevtić managed to gain only a slight majority of the votes, despite the highly favorable election law. The large number of votes for the Joint Opposition, consisting of the major pre-1929 parties (Radicals and SLS not included), convinced PrinceRegent Pavle that Jevtić enjoined very little actual support and that he would be incapable to solve the increasingly urgent Croatian question. Pavle then invited Milan Stojadinović, Finance Minister in Jevtić's government and former member of the Radical Party, to form a new government (Stojkov, Vlada 7-11). This meant the actual end of the Royal Dictatorship of King Aleksandar and of integral Yugoslavism as its official national ideology.

\section{Stojadinović's government (1935-1939)}

Stojadinović formed a government, which consisted of politicians formerly affiliated with the Radical Party, the Slovenian People's Party and the Yugoslav Muslim Organization Stojadinović gradually abandoned integral Yugoslavism in favor of what historians have termed real Yugoslavism (Dimić 1: 329-95). ${ }^{33}$ The clearest formulation of this real Yugoslavism can be found in the 1935 program of the Yugoslav Radical Union (JRZ, Jugoslovenska radikalna zajednica), the new ruling party consisting of a group of Radicals supporting Stojadinović, SLS and JMO. The party explicitly dissociated itself from JNS integralists who, in their view, had only aggravated the Croatian question. Indeed, the party intended to fully solve the Croatian question, not in an authoritarian way, but in an atmosphere of mutual respect and cooperation. Thus, the party's explicit recognition of tribal differences can only be understood as a reaction against the authoritarian character of the previous regime and its integral Yugoslav ideology.

[T] he territories our state consists of have lived their own particular lives and have obtained separate administrative, political and other habits over a long period of time. In order to develop and strengthen the consciousness of the unity of our state and our nation, and to equalize and reduce the differences our long and unequal past bequeathed us as good and wise as possible, the Party considers that the only political method to do so is to work gradually and sensibly, not to use outdated methods and not to try to create new feelings that way. Respect for the three names of our nation - Serb, Croat and Slovene - and their equality, respect for traditions, all that has to be protected, because that way the people will develop mutual respect, trust and consideration. (Qtd. in Stojkov, Vlada 54-55)

Thus, unlike integral Yugoslavists, who claimed that historical differences were only superficial and of no importance for Yugoslav national unity, and Radicals in the twenties, who adopted $\mathrm{a}$ - from a nationalist point of view - somehow hybrid national ideology, which accepted the existence of a Yugoslav nation but at the same time acknowledged tribal differences within that nation, JRZ adopted an ideology of a gradual synthesis of all positive tribal characteristics into one Yugoslav (supra-)nation. ${ }^{34}$ As mentioned in its program the party intended "to strengthen the harmony between Serbs, Croats and Slovenes as much as possible, to nurse the idea of Yugoslavism, of the Yugoslav totality as a synthesis of all positive characteristics and creative forces of all parts of the Yugoslav nation" (qtd. in Dimić 1: 337-38). For JRZ, Yugoslavism was something for the future. The present reality, hence the name real Yugoslavism, was that different tribal traditions had to be recognized and respected.

In practice this meant that Stojadinovic saw his party and government as the representatives of three parts of the Yugoslav nation, each of them with sufficient autonomy 
toward their own region: Slovenes under SLS representatives, Bosnian Muslims under JMO politicians and Serbs under Stojadinović's Radicals. ${ }^{35}$ A next step would be for the Croats too to have their representatives in government (Stojadinovic $317-22,498-99) .{ }^{36}$ Indeed, Stojadinović made attempts to reach an agreement with the Croatian Peasant Party, and although it can be discussed to which extent Stojadinović genuinely favored such an agreement, it is clear that his government recognized the urgency of the Croatian question (Djokić, Elusive Compromise 115-18; Stojadinović 465-70). ${ }^{37}$

What is more striking for the argument of this article is that in the discourse of Stojadinović and his ruling elite much less attention was paid to Yugoslavism in comparison to the twenties and certainly to the period of the Royal Dictatorship. Whereas in previous periods Yugoslavism had taken a prominent place in the elites' national discourse, it appeared only seldom in Stojadinović's discourse. What is more, JRZ openly criticized the integral Yugoslavism of the dictatorial regime for denying the existence of Serbian, Croatian and Slovenian nationalisms. In the words of JRZ Senator Dragoslav Đorđević "the danger for this state lies not in Serbianism, Croatianism or Slovenianism, not in Serbian, Croatian or Slovenian nationalism" but in "the new, bookish, doctrinarian, anemic and abstract Yugoslav nationalism, which denies Serbian, Croatian and Slovenian nationalism" (qtd. in Bakić 360). In a speech in parliament Stojadinović agreed with Đorđević that "we are one nation and [at the same time] we are not one nation" (qtd. in Bakic 360). However, what really mattered for Stojadinović was that the Croats were satisfied in Yugoslavia, just like the Serbs and the Slovenes (Bakić 360-361).

Consequently, the new government intended to loosen some of the integral Yugoslav elements of cultural politics under the dictatorship. This did not mean that JRZ radically broke with the integral Yugoslav cultural politics of the dictatorship. The curriculums that were adopted during the dictatorship remained valid and the few new curriculums that were issued did not differ from the previous ones. For example, the new curriculum for civil schools, which was adopted in 1936, prescribed the familiar approach toward Yugoslav history. ${ }^{38}$ For literature courses the students should read extracts from writers from the different historical regions in Yugoslavia as part of a larger Yugoslav literature (Kingdom of Yugoslavia, "Nastavni plan i program za I, II, III i IV razred građanskih škola" passim). However, as Dragoslav Đorđević made clear in a Senate speech about history textbooks clarifies, the governmental party adhered to a different interpretation of the Yugoslav national identity:

\footnotetext{
Our history textbooks should contain the histories of Croats, Slovenes and Serbs, and not the history of Yugoslavia, because the history of Yugoslavia, in its literal and wider meaning, not in its widest and most extreme version, only begins in 1918. In those textbooks Tomislav, Kresimir, Petar Svačić, Matija Gubec and their equals should not be Yugoslav, but Croatian kings, giants and martyrs. Prešern, Cankar and others should be freely called Slovenian giants. Let the Nemanjići, Karađorđe and Miloš be Serbian and not Yugoslav kings, tsars, giants and martyrs. Let the heroic army at Kumanovo be a Serbian and not a Yugoslav army et cetera. Historical facts should not be hidden, history should not be falsified in our textbooks! (Qtd. in Dimić 1: 353-54)
}

Indeed, in 1938 Education Minister Dimitrije Magarašević issued a new decree that allowed the use of textbooks that focused on the specific cultural spheres within the country and not so much on the integrality of Yugoslav culture (Dimić 1: 376-77). Interior Minister Korošec also took measures against integral Yugoslav organizations. The Sokol for example, one of the pillars of the dictatorship's cultural politics, gradually lost its privileged position, especially in Dravska banovina (Žutić, Sokoli 103-226). ${ }^{39}$

The Yugoslav national idea gradually disappeared from the political and cultural scene and its impact as a factor in the dynamic model of Yugoslav national identities decreased. That would become even more the case in the period after the formation of a new government in 1939, when a separate Croatian banovina was created with effective autonomy (Dimić 1: 
396-424; Djokić, Elusive Compromise 171-222). In practice, Yugoslavism as a national idea lost ground. Only the concept of several national parts within a Yugoslav multi-national state unity remained viable.

\section{Conclusion}

During all three periods of political rule under scrutiny, the national ideology of the ruling elites was essentially Yugoslav in character. All three ruling political elites I have discussed, accepted the existence or desirability of a Yugoslav nation to some extent. Contrary to the views of scholars as Banac or more recently Bakić, I have tried to show that the Yugoslavism of the ruling elites cannot be reduced to a merely tactical choice to protect Serbian national interests. This is not to say that regional/tribal/national interests played no role whatsoever in the dynamic formulation of Yugoslav national identities and ideologies. It is to say, that even when Serbian, Croatian or Slovenian interests acted as interpretive lenses in the dynamics of national identity, the end product could be Yugoslavism. It is only if one supposes national identities to be fixed and singular matters that every Yugoslavism has to be perceived through the lenses of today's dominant national ideologies and identities, as Serbian, Croatian or Slovenian nationalism in disguise.

Agreeing with Wachtel that "although political and social disagreements threatened the stability of the first Yugoslav state, its real failure was its inability to create a consensus regarding the twin concepts of the Yugoslav nation and its culture" (68), I have focused on the failure of ruling political elites to reach a consensus regarding the Yugoslav national idea as a framework within which the Yugoslav national identity could be elaborated on by a wider range of political and cultural elites. Although, as noted before, at the beginning of the period some form of Yugoslavism was accepted by governmental as well as opposition parties, ruling elites failed to create incentives for further interactive, negotiated and dynamic redefinitions of Yugoslav national identity. As Bulatović puts it: "Even if we assume that a new multi-ethnic Yugoslav identity was as achievable as any other, that process would require a longer, much better organized and more systematic process of 'imagination' and 'invention"' (268). As we have seen, in the discourse on education policy Yugoslavism took a prominent place throughout the period. However, during the twenties, no actual reforms were carried out toward the creation of a unified Yugoslav cultural space through education reforms, although, as Wachtel has shown, in the cultural arena there was considerable support and creativity to accomplish such a cultural unification (67-127). During the Royal Dictatorship, several measures were taken toward a Yugoslavization of the education system. However, the authoritarian nature of the regime quickly caused animosity toward Yugoslavism as a national idea itself, since that idea was so fundamental and omnipresent in the discourse of the dictatorial regime. Moreover, the intolerance toward political and cultural options other than the official version of integral Yugoslavism and centralism left little room for negotiation and interaction, basic traits of all successful national identities. ${ }^{40}$ Consequently, the rich Yugoslav national idea, which had been popular among educated circles all over Yugoslavia, became linked to conservatism, centralism, authoritarianism and for non-Serbian elites increasingly to Serbian hegemony. ${ }^{41}$ Yugoslavism on the one and Serbianism, Croatianism or Slovenianism on the other became increasingly perceived as competing, opposing national ideas within the framework of the Yugoslav state. When the dictatorial regime lost its legitimacy after Aleksandar's death, Yugoslavism as a national idea gradually lost ground. It only survived as the idea of a multinational state. 


\section{NOTES}

Research for this article was made possible thanks to the generous support of the Research Foundation Flanders (FWO). The author would like to thank the Nationalities Papers' referees for helpful comments on drafts of the article. An earlier version of this paper was presented at the $14^{\text {th }}$ annual convention of the Association for the Study of Nationalities, New York, 23-25 April 2009.

${ }^{1}$ See for example Gligorijević ("Jugoslovenstvo"); Pavlović; Suppan; Žutić ("Ideologija jugoslovenstva”). This article will not mention Montenegrin, Bosniak or Macedonian national identities, since during the interwar period the ruling political elites I focus on did not consider them constituent parts of the Yugoslav nation. It should however be argued that the interwar period was of great importance for the development of these national identities.

${ }^{2}$ Indeed, throughout his book Djokić hints at the dynamic and overlapping character of Yugoslav, Serbian and Croatian national ideas, suggesting that "it is debatable whether Serbian and Croatian nationalisms had been formed by 1918, and whether they remained immune to evolution following the creation of Yugoslavia" (Elusive Compromise 7).

${ }^{3}$ This typology of Yugoslavism draws on the one which was suggested by Dimić (1: 191-395) and later adopted by Bakić (85-86). Bakić has categorized the national ideologies of both the Radicals in the twenties and the government of Stojadinović as real Yugoslavism. In order to make a clear distinction between both periods, I have opted for the term compromised Yugoslavism for the first period, following Dimić who has termed the national idea of the ruling elites during the twenties "compromised national unitarism" (1:213).

${ }^{4}$ In March 1924 a branch of the Democratic Party formed an Independent Democratic Party (SDS, Samostalna demokratska stranka) under the leadership of Svetozar Pribićević. Independent Democrats disagreed with the Democrats' more tolerant position toward a decentralization of Yugoslavia. However, both parties remained advocates of Yugoslavism (Gligorijević, Parlament 159-62).

${ }^{5}$ King Aleksandar's vision on the Yugoslav national question will be discussed in the following section.

${ }^{6}$ The Radical Party was formed in the eighties of the nineteenth century in independent Serbia. After the 1903 coup it became the country's dominant party (Gligorijević, Parlament 7-10).

${ }^{7}$ During the interwar period the term "tribe" (pleme) was commonly used to denote the Serbian, Croatian and Slovenian branch of the Yugoslav nation. This makes clear to which extent the notion of a Yugoslav nation was accepted by the political elites of the period. At the same time, however, it clarifies that differences within the Yugoslav nation had to be addressed somehow and could not be simply ignored. Throughout this article, the terms tribe and tribal will be used solely in this meaning.

${ }^{8}$ The quotation is from Samouprava, the official newspaper of the Radicals. All translations in this paper are mine, except when noted otherwise.

${ }^{9}$ This overlap between Yugoslavism and "narrow" national ideas was not only characteristic of the Radicals. There can be no place here for a detailed overview of all political parties in Yugoslavia, but suffice it to refer to the examples Djokić provides of the overlap of Yugoslav and Croatian national ideas in the discourse of Stjepan Radić, the leader of the Croatian (Republican) Peasant Party (H(R)SS, Hrvatska (republikanska) seljačka stranka) (Elusive Compromise esp. 29-30, 31-35, 51-53). The same point can be made for two other parties that frequently joined government, the Slovenian People's Party (SLS, Slovenska ljudska stranka) and the Yugoslav Muslim Organization (JMO, Jugoslovenska muslimanska organizacija) (Banac 340-51, 359-77).

${ }^{10}$ Articles 2 and 3 of the 1921 Constitution (Mrđenović 209).

${ }^{11}$ Article 16: "All schools have to provide moral education and develop civic consciousness in the spirit of national unity and religious tolerance" (Mrđenović 211).

${ }^{12}$ A first curriculum was adopted in June 1925, but was never implemented. It was replaced by a new curriculum on 9 August 1926. Due to severe criticism this curriculum was again replaced by a temporary curriculum in October 1927. However, the differences between these curriculums were actually negligible (Dimić 2: 121; Mayer 72).

${ }^{13}$ See Bakić (298-348, 363-401) and Banac (153-189).

${ }_{15}^{14}$ As already mentioned, this point could also be made for other political elites of the period.

${ }^{15}$ For the Yugoslav ideologies of both centralist and decentralist parties during and right after the First World War, see Djokić (Elusive Compromise 12-75). For cultural Yugoslavism during the interwar period, see Wachtel (67-127). The decreasing popularity of Yugoslavism during the twenties was most obvious among non-Serbian elites and was expressed as opposition against Serbian hegemony. Serbian elites remained more favorable toward Yugoslavism, and it was only by the end of the interwar period that disillusion with Yugoslavism as a national idea grew among Serbian elites too.

${ }^{16}$ The Council of Ministers consisted mostly of dissident politicians affiliated with the formally forbidden Radical and Democratic Party. The King also tried to include representatives of other tribes in his government. 
SLS leader Anton Korošec became Minister of Traffic until he broke with the regime in 1930. Later, in September 1931, the government was joined by two Slovenian integral Yugoslavists: Albert Kramer, former member of the Democratic Party, and Ivan Pucelj, former leader of the Independent Agrarian Party (SKS, Samostojna kmetijska stranka). Throughout the dictatorship the government also included several Croatian representatives, mostly HSS dissidents, and some Bosnian JMO dissidents. General Petar Živković became the first prime minister (Nielsen 127-32; Stojkov, Opozicija 72-109, 133-43).

${ }^{17}$ Dravska banovina corresponded to Slovenia, Savska and Primorska to Croatia-Slavonia and Dalmatia, the six other banovine (Dunavska, Vrbaska, Drinska, Moravska, Vardarska and Zetska) had a Serbian majority, again an indication of Serbian dominance. All banovine except Primorska (Coastal) were named after rivers (Djokić Elusive Compromise 72-74).

${ }^{18}$ Governmental declaration presented by Petar Živković at the XXI session of the Council of Ministers, 4 July 1930 (Dimić, Žutić and Isailović 193).

${ }^{19}$ Petar Živković at the XXIII session of the Council of Ministers, 3 October 1929 (Dimić, Žutić and Isailović $100)$.

${ }^{20}$ The Sokol (Czech, literally 'falcon') was a youth gymnastics movement with a specific tradition in the Slavic world. The first Sokol was founded in 1862 in Prague by Miroslav Tyrš. It was not only a gymnastics movement, but also an organization through which the nation was nationally educated. Later, similar movements were established in other Slavic lands, all combining gymnastics with national education. In the Yugoslav lands a Croatian, Serbian, Slovenian and Yugoslav Sokol were founded, all of which were disbanded and replaced by the Sokol of the Kingdom of Yugoslavia in 1929 (Žutić, Sokoli 5-80).

${ }^{21}$ For more details on the consolidation of the dictatorship see Dobrivojević $(44-59,95-122)$ and Nielsen (123239).

${ }^{22}$ On 3 September 1931 the King installed a semi-parliamentary system. I deal with this more extensively in the following paragraph.

${ }^{23}$ Petar Živković at the XXIII meeting of the Council of Ministers on 25 August 1930 (Dimić, Žutić and Isailović 200). Famously, a party rally in Niš in April 1933 ended in complete chaos because of the rain and the very large number of people using the free train tickets the regime offered for the occasion as a unique opportunity to visit Niš rather than to express their support for the regime (Dobrivojević 131-32).

${ }^{24}$ VI session of the Council of Ministers, 14 March 1929 (Dimić, Žutić and Isailović 35).

${ }^{25}$ Jugoslovenski dnevnik was a daily appearing from 1929 until 1935, first in Subotica and later in Novi Sad, under the redaction of integral Yugoslav publicist and politician Fedor Nikić.

${ }^{26}$ Not surprisingly, religious instruction was closely checked by the state, since religion was considered to be the most important factor of division within the Yugoslav nation. Religion teachers stood under the strict supervision of the authorities at the level of the banovine. Curriculums for religious instruction were issued by the Ministry of Education. In both cases the different religious authorities could only act as advisory organs. Students' organizations could not be based on religious or tribal factors. Outside school, religious organizations were permitted, but only for cherishing religious sentiments (Kingdom of Yugoslavia, "Zakon o verskoj nastavi" passim).

${ }_{27}$ The orthographic instructions stated that "[i]n the Serbo-Croatian literary language both alphabets, Latin and Cyrillic, are equal (Kingdom of SCS, "Pravopisno uputstvo" 3)." Indeed, we see that Yugoslav orientated publications, such as Jugoslovenski Dnevnik or Almanah Kraljevine Jugoslavije ('Almanac of the Kingdom of Yugoslavia'), used the Latin and Cyrillic alphabet alternately.

${ }^{28}$ Grgur Ninski was bishop in Nin in present-day Croatia in the $10^{\text {th }}$ century. He supported the use of Old Slavonic as the language for liturgy.

${ }_{29}$ Tvrtko I Kotromanić (1353-1391) was the ruler of a kingdom consisting of present-day Bosnia-Herzegovina, as well as parts of Croatia, Serbia and Montenegro.

${ }^{30}$ Mihailo Obrenović was Prince of Serbia between 1839-1842 and again between 1860-1868, and favored political cooperation between the South Slavs, under his leadership. Bleiweis was a Slovenian publicist who founded a journal favoring South Slavic cooperation in 1843.

${ }^{31}$ It should be mentioned that this Yugoslav interpretation of South Slav historical events was not completely new. The interpretation of the Kosovo myth as a Yugoslav myth for example was already well established through the work of Ivan Meštrović at the beginning of the $20^{\text {th }}$ century (Wachtel 53-59).

${ }^{32}$ These were the 10 figures, with their tribal affiliation: Cyrillus and Methodius (commemorated by Orthodox and Catholics, although through the use of the Cyrillic alphabet and Old Slavonic in liturgy more closely linked with the Serbian tribe), St Sava (Serbian), Prince Marko (Serbian), prince Lazar (Serbian), Nikola Šubić Zrinjski (Croatian), Karađorđe (Serbian), Strossmayer (Croatian), King Petar (Serbian), King Aleksandar (Serbian).

${ }_{33}$ Bakić applies the term real Yugoslavism for both the Radicals in the twenties and Stojadinović's government (298-363). I have opted not to do so in order to make a clear distinction between the Radicals in the twenties, who claimed that tribal differences did not harm Yugoslav national unity, and Stojadinović's government, which 
held that the Yugoslav national unity could only be fully realized in the future, through mutual respect and cooperation between the Yugoslav tribes. I elaborate on this point in the following paragraphs.

${ }^{34}$ I placed "supra-" in parentheses because it is not clear whether JRZ envisaged a complete assimilation of the three tribes into a Yugoslav nation or a harmonic cooperation of three nations within one supranational community. For more examples of how Stojadinović's discourse included both Yugoslav and tribal elements, see Djokić (Elusive Compromise 173-81).

${ }^{35}$ Especially Slovenia (Dravska banovina) was said to form a state within the state under the undisputed leadership of Anton Korošec (Dimić 1: esp. 349-52).

${ }^{36}$ Stojadinović compared his government to a three-legged chair and stated that his government would not be completely stabile until a fourth, Croatian leg was included (Stojadinović 318).

${ }^{37}$ Stojadinović and Maček met once in January 1937 but failed to reach a concrete agreement (Stojadinović 465 70). Apparently, Maček preferred to negotiate with Prince Pavle, with whom he met in June 1935 and November 1936 (Djokić, Elusive Compromise 118).

${ }^{38}$ Civil schools could be attended by students who had finished lower elementary school and provided technical education in three specific directions: trade, industry and agriculture.

${ }^{39}$ Dravska banovina comprised largely Slovene lands.

${ }^{40}$ For a stimulating elaboration on the negotiated character of national identities, see Applegate (esp. 1174-79).

${ }^{41}$ Indeed, Serbian politicians dominated Yugoslav governments throughout the interwar period. Consequently, Serbian symbolic resources were overrepresented in their definitions of Yugoslavism and there was too little space for non-Serbian views on Yugoslavism. It should be stressed however that a majority of the Serbian elites too became disillusioned with Yugoslavism by the end of the interwar period (Bulatović 264-68; Djokić, Elusive Compromise 223-68).

\section{REFERENCES}

Applegate, Celia. "A Europe of Regions: Reflections on the Historiography of Sub-National Places in Modern Times.” American History Review 104 (1999): 1157-82. Print.

Aranicki, Kosta V. and Stevan Karadžić, eds. Najnoviji jugoslovenski učiteljski zbornik svih zakona, uredaba, pravilnika, pravila, rešenja, odluka i raspisa izdatih od oslobođenja do danas, koji se odnose na narodne škole $i$ narodne učitelje-ice u celoj Jugoslaviji, a i danas su u važnosti. Zrenjanin: Napredak, 1935. Print.

Bakić, Jovo. Ideologije jugoslovenstva između srpskog i hrvatskog nacionalizma. Zrenjanin: Žarko Zrenjanin, 2004. Print.

Banac, Ivo. The National Question in Yugoslavia. Origins, History, Politics. Rev. ed. Ithaca, NY: Cornell UP, 1988. Print.

Brubaker, Rogers. Nationalism Reframed: Nationhood and the National Question in the New Europe. Cambridge: Cambridge UP, 1996. Print.

Bulatović, Marko. "Struggling with Yugoslavism: Dilemmas of Interwar Serb Political Thought." Ideologies and National Identities, The Case of Twentieth-Century Southeastern Europe. Ed. John R. Lampe and Mark Mazower. Budapest: Central European UP, 2004. 254-76. Print.

Čulinović, Ferdo. Dokumenti o Jugoslaviji: Historijat od osnutka zajedničke države do danas. Zagreb: Školska knjiga, 1968. Print

Dimić, Ljubodrag. Kulturna politika u Kraljevini Jugoslaviji 1918-1941. 3 vols. Belgrade: Stubovi kulture, 1996/1997. Print.

Dimić, Ljubodrag, Nikola Žutić and Blagoje Isailović, eds. Zapisnici sa sednica ministarskog saveta Kraljevine Jugoslavije. Belgrade: Službeni list SRJ/Arhiv Jugoslavije, 2002. Print.

Djokić, Dejan. “(Dis)Integrating Yugoslavia: King Alexander and Interwar Yugoslavism.” Yugoslavism: Histories of a Failed Idea, 1918-1992. Ed. Dejan Djokić. London: Hurst \& Co, 2003. 136-56. Print.

Elusive Compromise. A History of Interwar Yugoslavia. London: Hurst \& Co, 2007. Print.

Dobrivojević, Ivana. Državna represija u doba diktature Kralja Aleksandra, 1929-1935. Belgrade: Institut za savremenu istoriju, 2006. Print.

Gligorijević, Branislav. Parlament i političke stranke u Jugoslaviji (1919-1929). Belgrade: Institut za savremenu istoriju, 1979. Print.

“Jugoslovenstvo između dva rata.” Jugoslovenski istorijski časopis 21 (1986): 71-97. Print.

Karađorđević, Aleksandar I. "Govor Kralja Aleksandra u Narodnoj Skupštini povodom proglašenja Ustava od 3.IX-1931”, 1932. Archive of Yugoslavia (henceforth AJ) (fond)74-(fascicle)38-(group)56.

Kaufmann, Eric. “The Lenses of Nationhood: An Optical Model of Identity." Nations and Nationalism 14 (2008): 449-77. Print.

Kingdom of Serbs, Croats and Slovenes (SCS). "Zakon o centralnom presbirou." Sluzbene novine 22 Nov. 1929, 2039. Print. 
Ministry of Education. "Nastavni program za I, II, III i IV razred osnovnih škola Kraljevine Srba,

Hrvata i Slovenaca." Belgrade: državna štamparija, 1926. Print.

- Ministry of Education. "Pravopisno uputstvo za sve osnovne, srednje i stručne škole Kraljevine S.H.S."

1929. AJ 66-319-537.

Ministry of Interior. “Zakon o izmenama i dopunama zakona o štampi.” Službene novine 11 Jan. 1929:

56-57. Print.

- Ministry of Interior. "Zakon o zaštiti javne bezbednosti i poretka u državi." Službene novine 11 Jan.

1929: 54-56. Print.

- Ministry of Interior. "Zakon o nazivu i podeli Kraljevine na upravna područja." Službene novine 5 Oct. 1929: 1885-89. Print.

Kingdom of Yugoslavia. "Statut o organizaciji i poslovanju Sokola Kraljevine Jugoslavije." Službene novine 15 Feb. 1930: 315-20. Print.

_ Ministry of Education. "Nastavni plan i program za osnovne škole u Kraljevini Jugoslavije." 1933. AJ 66-1281.

1281.

_ Ministry of Education. "Zakon o verskoj nastavi u narodnim, građanskim, srednjim i učiteljskim

školama u Kraljevini Jugoslaviji." Službene novine 17 Oct. 1933: 1233-34. Print.

Ministry of Education. "Nastavni plan i program za I, II, III i IV razred građanskih škola u Kraljevini Jugoslavije." 1936. AJ 66-653A.

Mayer, Martin. Elementarbildung in Jugoslawien (1918-1941). Ein Beitrag zur gesellschaftlichen

Modernisierung? München: R. Oldenbourg, 1995. Print.

Mrđenović, Dušan. Ustavi i vlade Kneževine Srbije, Kraljevine Srbije, Kraljevine SHS i Kraljevine Jugoslavije

1835-1941. Belgrade: Nova knjiga, 1988. Print.

"Načele Jugoslovenske nacionalne stranke." Jugoslovenski dnevnik 22 July 1933: 2-3. Print.

Nielsen, Christian Axboe. One State, One Nation, One King: The Dictatorship of King Alexander and His

Yugoslav Project, 1929-1935. Ph. Diss., Columbia U, 2002. Print.

Pavlović, Stevan K. "Jugoslavija 1918-1991. Poraz jednog identiteta i jedne nestabilne političke culture.” Istorija XX veka 14 (1996): 7-20. Print.

Stanković, Đorđe. Nikola Pašić i jugoslovensko pitanje. Vol. 2. Belgrade: Beogradski izdavačko-grafički zavod, 1985. Print.

Stojadinović, Milan. Ni rat, ni pakt. 2nd ed. Rijeka: Otokar Keršovani, 1970. Print.

Stojkov, Todor. Opozicija u vreme šestojanuarske diktature, 1929-1935. Belgrade: Prosveta, 1969. Print.

- Vlada Milana Stojadinovića, 1935-1937. Belgrade: Institut za savremenu istoriju, 1985. Print.

Suppan, Arnold. "Yugoslavism versus Serbian, Croatian and Slovenian Nationalism." Yugoslavia and Its Historians. Understanding the Balkan Wars of the 1990s. Ed. Norman M. Naimark and Holly Case. Stanford, CA: Stanford UP, 2003. 116-139. Print.

Tešić, Vladeta. Sto godina prosvetnog saveta Srbije: 1880-1980. Belgrade: Zavod za udžbenike i nastavna sredstva, 1980. Print.

Wachtel, Andrew Baruch. Making a Nation, Breaking a Nation. Literature and Cultural Politics in Yugoslavia. Stanford, CA: Stanford UP, 1998. Print.

“Za uspešno sprovođenje prosvetne politike.”Jugoslovenski dnevnik 18 Apr. 1930: 1. Print.

Zimmer, Oliver. "Boundary Mechanisms and Symbolic Resources: Towards a Process-Orientated Approach to National Identity." Nations and Nationalism 9 (2003): 173-193. Print.

Žutić, Nikola. "Ideologija jugoslovenstva i njeno raspadanje (1929-1939), s posebnim osvrtom na vladu M.

Stojadinovića." Istorijski glasnik, no. 1-2 (1988): 63-91. Print.

- Sokoli. Ideologija u fizičkoj kulturi Kraljevine Jugoslavije 1929-1941. Belgrade: Angrotrade, 1991. Print. 